\title{
GENETIC VARIABILITY OF THE VP1 GENE OF BK AND JC POLYOMAVIRUSES IN HIV-INFECTED PATIENTS
}

\author{
Danijela Karalić ${ }^{1}$, Ivana Lazarević ${ }^{1}$ \\ ${ }^{1}$ Institute of Microbiology and Immunology, Faculty of Medicine, University of Belgrade, Serbia \\ Contact e-mail: danijela.karalic@mfub.bg.ac.rs
}

Abstract

Human polyomaviruses, BK virus (BKV) and JC virus (JCV), are world widely distributed in human population. After primary infection, BKV and JCV establish latency in kidneys and upper part of urinary tract. In seropositive healthy individuals asymptomatic reactivation of both viruses occurs in in $0.5-20 \%$. On the other hand, reactivation of these viruses in imunosuppressed patients, primarily in patients with $\mathrm{T}$ cell immunodeficiency, can lead to development of polyomavirus-associated diseases. Some of these diseases such as progressive multifocal leukoencephalopathy (PML), polyomavirusinduced nephropathy (PVN), hemorrhagic cystitis (HC) are life-threatening diseases with high mortality and morbidity rate.

However, they do not affect all immunosuppressed patients, suggesting that other factors, such as genetic variability of BKV and JCV, can contribute to their occurrence.

Immunosuppression leads to increased levels of replication of both viruses. Increased levels of replication are associated with higher incidence of mutations in the VP1 gene. Mutations, especially those located in outer loops, may lead to changed tropism and generation of more aggressive variants of BKV and JCV. This review is focused on clinical significance of BK and JC virus infection in immunosuppressed patients, especially in HIV-infected, and sequence changes in the VP1 gene that can contribute to selection of more virulent variants of BKV and JCV via adaptive evolution.

Key words: BKV, JCV, HIV, mutations, VP1

\section{Sažetak}

Humani poliomavirusi, BK virus (BKV) i JC virus (JCV), su široko raspostranjeni u humanoj populaciji. Posle primarne infekcije, BKV i JCV uspostavljaju latenciju u bubrezima i u gornjim partijama urinarnog trakta. Sporadična asimptomatska reaktivacija oba virusa se dešava kod 0.5-20\% imunokompetetnih seropozitivnih osoba. S druge strane, reaktivacija kod imunosuprimiranih pacijenata, pre svega kod onih sa $\mathrm{T}$ ćelijskom imunodeficijencijom, može dovesti od nastanka poliomavirus-udruženih oboljenja. Neka od ovih oboljenja poput progresivne multifoklane leukoencefalopatije (PML), poliomavirus-udružene nefropatije (PVN), hemoragijskog cistitisa (HC) su životno ugrožavajuća sa visokim stepenom mortaliteta i morbiditeta.

Međutim, ova oboljenja ne nastaju kod svih imunosuprimiranih osoba, ukazujući da i neki drugi faktori, poput genetičke varijabilnosti BKV i JCV mogu doprineti njihovom nastanku.

Imunosupresija dovodi do povećanja nivoa virusne replikacije. Povećan nivo replikacije je povezan sa češćom pojavom mutacija u VP1 genu i ove mutacije, posebno one locirane u spoljašnjim domenima, mogu dovesi do izmene tropizma i stvaranju novih agresivnijih varijanti BKV i JCV. Akcenat u ovom revijskom radu je stavljen na klinički značaj BK i JC virusne infekcije kod imunosuprimiranih pacijenta, $s$ posebnim osvrtom na HIV-inficirane pacijente, i na mutacije u okviru VP1 gena koje mogu doprineti evolutivnoj selekciji virulentnijih varijanti BKV i JCV.

Ključne reči: BKV, JCV, HIV, mutacije, VP1

\section{Introduction}

Seroepidemiological studies have shown that between $27 \%$ and $80 \%$ of the human population is infected with two human polyomaviruses: BK virus (BKV) and JC virus (JCV). The primary infection, which occurs during early childhood, is usually asymptomatic or is manifest- ed as mild respiratory disease [1]. After the primary infection, both viruses establish latency in cells of the kidneys and upper parts of the urinary tract. Beside kidneys, JCV also establishs latency in B lymphocytes and in other cells of monocytic lineage. During life of seropositive immunocompetent individuals sporadic asymptomatic reactivation of both viruses occurs in $0.5-20 \%$ [2]. On the other hand, in immunosuppressed patients reactivation 
of these viruses can lead to the development of serious and life-threatening diseases.

Virions of human polyomaviruses are among the smallest of DNA viruses and have spherical shape, with icosahedral capsid symmetry without envelope. Virions enclose a single molecule of circular double-stranded DNA of approximately $5 \mathrm{kbp}$ that is associated with cell histones $\mathrm{H} 2 \mathrm{~A}, \mathrm{H} 2 \mathrm{~B}, \mathrm{H} 3$ and $\mathrm{H} 4$. Icosahedral capsid is composed of three viral capsid proteins VP1, VP2 and VP3. It comprises 72 capsomers, where each capsomer is composed of 5 molecules of VP1 that is associated with single molecule of VP2 and VP3. VP1 has an essential role in host-cell receptor binding [3].

The genomes of BKV and JCV are divided into three regions: the early coding region, late coding region and hypervariable non-coding regulatory region (NCRR). The early coding region, encodes small (t Ag) and large $\mathrm{T}$ antigen $(\mathrm{T} \mathrm{Ag})$; late coding region encodes VP1, VP2, VP3 and agnoprotein [4]. Noncoding regulatory region (NCRR), the most variable part of the genome, contains the origin of replication (ori), TATA region, bidirectional promoters and enhancers, binding sites for T-Ag and cellular transcription factors.

\section{The clinical significance of BK and JC viral infections}

$\mathrm{BKV}$ is the etiological agent of polyomavirus-associated nephropathy (PVN) and urethral stenosis in patients with transplanted kidneys, as well as hemorrhagic cystitis (HC) in patients after bone marrow transplantation [5]. Immunosuppressive drugs that are used for graft preservation in both groups of transplanted patients lead to reactivation of latent BK viral infection in the urinary tract.

Polyomavirus-associated nephropathy, the most common BKV-associated disease after renal transplantation, is a form of acute interstitial nephritis [6]. Reactivation of BKV followed by viruria and viremia occurs in $80 \%$ of patients with a kidney transplant. In $10 \%$ of these patients PVN will occur and lead to graft loss in almost $90 \%$ of cases $[7,8,9]$. The basic histopathological characteristics of PVN are proximal tubular necrosis and destruction of the basal membrane accompanied by fibrosis [10]. In recent years, the incidence of PVN has increased significantly due to the use of newer, more powerful immunosuppressive drugs [11]. Host and viral genetic factors beside immunosuppression, which is the most important risk factor, can also contribute to development of PVN. To date, an effective and specific antiviral therapy for BKV does not exist. Modulation of immunosuppressive therapy is usually done in order to help immune system to establish the control over BKV infection.
However, reducing the dose of immunosuppressive drugs in transplant patients can increase the risk of acute renal rejection.

Hemorrhagic cystitis is a serious BKV-associated complication which affects about $10 \%$ of patients after transplantation of bone marrow and is characterized by varying degrees of dysuria and hematuria [12]. HC is likely to occur as a consequence of BKV reactivation in the urothelium, as the BK virus particles can be detected in desquamated epithelial cells in the urine [13]. Viruria levels correlate with the degree of hematuria in patients with HC. Usually, BKV-associated HC occurs 10 days after transplantation and requires hospitalization and adequate medical treatment.

Progressive multifocal leukoencephalopathy (PML) is a sub-acute, degenerative and progressive disease of the central nervous system that occurs as a result of lytic infection of JCV in oligodendrocytes. Oligodendrocytes are the myelin producing cells of the CNS, and the basic histopathological characteristic of PML is presence of mutifocal lesions of demyelination in the white matter of the brain [14]. Clinically, patients with PML show numerous neurological symptoms and they are related to the location and amount of damage in the brain, and may evolve over the course of several weeks to months. The most prominent symptoms are clumsiness, muscle weakness that eventually turns into hemiplegia, cognitive decline with the onset of subcortical dementia, and visual, speech, and sometimes personality changes [15]. PML can occur at any time during life, even in childhood, but most often is diagnosed in adults with severe levels of immunosuppression. The median survival time is very short, from a few months to a year, and is conditioned by the level of immunosuppression and JCV replication rate in the CNS [16]. The specific antiviral therapy does not exist, and modification of the treatment for the underlying disease is usually carried out.

Before the AIDS epidemic, lymphoproliferative diseases were the leading cause for the reactivation of JCV and BKV, while nowadays HIV infection is the most common cause for reactivation of JCV and the development of PML [17].

\section{HIV infection and reactivation of BKV and JCV}

CD8+ cytotoxic T lymphocytes (CTL) are the most important cells of the immune system that control BKV and JCV infection. CTL are cells that recognize the epitopes within VP1 molecule and T antigen of the BKV and JCV. The basic characteristic of dysfunction of the immune system during HIV infection is reduced number 
of CD4+ T cells. A sufficient number of CD4+ T cells are necessary to have adequate response of CD8+ CTL in control of persistent viral infections [18]. Reduced or complete lack of CTL response due to a decrease in $\mathrm{CD} 4+\mathrm{T}$ cells is one of the reasons for higher replication rates of JCV and BKV in HIV- infected patients.

In addition, synergistic relationship between HIV and JCV/BKV occuring at the molecular level is another reason for more frequent polyomavirus reactivation in HIV-infected patients. Interestingly, HIV and JCV, have common site of latency: CD34+ hematopoietic progenitor cells of the bone marrow. These cells are reservoirs of both: HIV and JCV $[19,20]$. A non-structural protein of HIV, tat protein, has been shown to increase transcription of JCV [21]. HIV infected cells secrete tat protein that is uptaken by uninfected cells and therefore co-infection of cells with HIV and JCV is not necessary to achieve correlation at the molecular level between these two viruses [22]. The uptake of tat protein has been shown in oligodendrocytes, which supports theory of increased JCV transcription through synergistic relationship between HIV and JCV. Tat protein binds to the tat-binding sites within noncoding regulatory region (NCRR) of JCV and acts as an enhancer of transcription for early genes, primarily T antigen of JCV. Also, both JCV and HIV, use the same cellular transcription factors such as: proteins from the NF-1 family [23], Sp1 factor, and cellular protein called Pura [24]. Spi-B and NF-1 are transcriptional factors that bind to sequences in the JCV promoter/enhancer and it has been shown that they are upregulated in B cells, glial cells, and hematopoietic progenitor cells in which JCV can replicate [25]. HIV-1 tat protein also transactivates the BKV early promoter (BKVE) resulting in increased viral replication of BKV among HIV-infected patients. Tat stimulates BKVE by inducing binding of the NF-kB p65 subunit to a $\mathrm{kB}$ motif near the 3end of BKVE. Activation of BKVE results in production of early $\mathrm{T}$ protein antigen that binds to the origin of replication and is a key player in replicative phase of BKPyV infection [26].

Reactivation of JCV, primarily in patients with $\mathrm{T}$ cell immunodeficiency, leads to lytic infection of oligodendrocytes in the central nervous system and the development of PML [27]. Nowadays, eighty percent of patients with PML are HIV-infected patients. PML occurs in $1-10 \%$ of patients with AIDS and leads to a fatal outcome in $90 \%-95 \%$ of cases during the first year after diagnosis of PML [16] .Although the use of highly active antiretroviral therapy (HAART) has reduced the number of many opportunistic infections, the incidence of PML still remains high in HIV/AIDS patients. Although it is a rare disease, the incidence of PML is increasing due to the increased number of people living with AIDS. Lately, reactivation of JCV is also associated with the onset of new neurological disorders such as neuropathy, encephalopathy and meningitis [28].

JCV has the ability to infect and persist in the B lymphocytes, and these cells are responsible for the transmission of JCV from the kidney to the central nervous system. In the CNS, JCV leads to lytic infection of oligodendrocytes and the development of PML. However, in immunocompetent individuals JCV also infects B lymphocytes and can be transmitted to the CNS, but there is no development of PML. The rising question is, why?

One possible explanation is that in HIV-infected patients, state of immunodeficiency allows longer persistence of JCV infected B lymohocytes in the bloodstream, and thus increase the risk for the transmission of JCV to the CNS. Also, it has been observed that during HIV infection dysfunction of B lymphocytes associated with an increased circulation of the same, facilitates passing of the B lymphocytes infected with JCV through the blood-brain barrier [29]. Additionally, HIV tat protein directly increases the expression of early JCV genes, resulting in increased level of JCV replication rate in infected cells [21]. It seems that HIV infection by interfering with the immune system of the host, creates a favorable condition for the onset of PML.

In the last decade, wide range of diseases such as nephritis, pneumonia, encephalitis and retinitis are associated with reactivation of $\mathrm{BKV}$ in $\mathrm{HIV}$-infected patients $[30,31]$.

However, these diseases do not occur in all HIV-infected patients, so it is considered that other factors, such as genetic variability of the $\mathrm{BKV}$, can contribute to their development.

\section{The VP1 gene variability of BKV and JCV}

VP1 gene product is the viral capsid protein 1 (VP1) and belongs to a group of late structural genes of BKV and JCV. It is the most superficial molecule in the capsid which has a key role in binding to a receptor on the host cell. VP1 protein also has an epitope to which the immune system produces neutralizing antibodies [32].VP1 of both viruses consists of five outer loops (BC, $\mathrm{CD}, \mathrm{DE}, \mathrm{EF}, \mathrm{GH}$ and $\mathrm{HI})$ that are connected via $\beta$-sheets $(\beta-C, \beta-D, \beta-E, \beta-F)(3)$. External domains of BC and HI loops are the most important domain of the VP1 and play a crucial role in binding to cell surface receptors. Mutations in the VP1 gene, especially in outer loops, may alter biological characteristics of the virus and lead to the selection of more aggressive variants of the virus with different spread and infectivity [33]. 


\section{The clinical significance of VP1 gene variability}

The factors that influence JCV neurotropism and neurovirulence have not yet been fully clarified. It has been suggested that possible predictors for the development of PML are located within the polymorphic VP1 region of the JCV genome [34]. Sunyaev et al., [35] in their research identified four codons in the JCV genome (which correspond to the amino acids at positions 55, 60, 267 and 269) that are subjected to positive selection pressure by the immune response in patients with PML. Two deletions that consists of eight and nine amino acids within the DE domain of VP1 (aa125-132 and aa127134) have been described as the dominant forms of JCV in two AIDS patients with the PML [36]. In both patients, JCV clone with a deletion of amino acids showed better evolutionary fitness and replication advantage over clone without deletions.

BKV VP1 gene is frequently a target for point mutations. The mutations in this region can change the biological properties of the virus in favour of more aggressive BKV strains $[3,37,38]$. Secondary T cell immunodeficiency, the main characteristic of HIV infection, is the key factor of the BKV reactivation that leads to increase in viral replication. Higher turnover rate of BKV in HIV-infected patients creates a favorable environment for development of point mutations by increasing the error rate in BKV DNA replication $[39,40]$. Dugan et al. [3] suggested that amino acid changes at positions 73 and 82 did not affect viral replication while mutations at positions $61,64,65$ and 69 caused capsid instability and defective attachment to the host cell in vitro. Pastrana et al. [41] reported that polyomaviruses were under great selective pressure to accumulate mutations in VP1 capsid epitops in order to escape from neutralizing antibodies. Having in mind a crucial role of BC loop in BKV life cycle, these mutations may be a result of several factors such as state of immunosuppression caused by HIV infection in combination with host and viral genetics. All these factors together may lead to the selection of more aggressive BKPyV VP1 mutants with the best chances to spread and infect other organs apart from kidney [42].

\section{Conslusion}

In recent years, $\mathrm{BKV}$ and $\mathrm{JCV}$ are gaining more and more attention from scientists because of the high mortality rate of diseases occuring during their reactivation. Mutations in VP1 indicate genomic instability and specific mutations in VP1 gene of JCV carry a characteristic fingerprint for devolopment of PML. On the other hand, a strong link between BKV-associated diseases and mutations in VP1 gene of BKV is not yet established. It seems that mutations are not randomly dispersed in VP1 of BKV but that BC loop seems more exposed to mutations then other loops. Further investigations are needed to determine the effect of these mutations on biological and pathological properties of the BKV. Knowing the severity of disease resulting from reactivation of $\mathrm{BKV}$ and JCV, patients with HIV/polyomavirus co-infection should be kept under more frequent and regular supervision in order to identify and select those with higher risk of developing polyomvirus-associated diseases.

\section{References}

1. Goudsmit J, Baak ML, Sleterus KW, Van der Noordaa J. Human papovavirus isolated from urine of a child with acute tonsillitis. Br Med J 1981;283:1363-1364.

2. Eash S, Manley K, Gasparovic M, Querbes W, Atwood WJ. The human polyomaviruses. Cell Mol Life Sci 2006;63:865876.

3. Dugan AS, Gasparovic ML, Tsomaia N, Mierke DF, O’Hara BA, Manley $\mathrm{K}$, et al. Identification of amino acid residues in BK virus VP1 that are critical for viability and growth. J Virol 2007;81:11798-11808.

4. Moens U, Rekvig P. Molecular biology of BK virus and clinical and basic aspects of BK virus renal infection. In: Khalili K, Stoner G, editors. Human polyomavirus: Molecular and clinical perspectives. Wiley-Liss New York; 2001. p. 359-408.

5. Sukov W, Lewin M, Sethi S, Rakowski TA, Lager DJ. BK virus associated nephropathy in a patient with AIDS. Am J Kidney Dis 2008;51:e15-e18.

6. Nickeleit V, Mihatsch MJ. Polyomavirus nephropathy in native kidneys and renal allografts: an update on an escalating threat. Transpl Int 2006;19:960-973.

7. Binet I, Nickeleit V, Hirsch HH, Prince O, Dalquen P, Gudat F, et al. Polyomavirus disease under new immunosuppressive drugs: a cause of renalgraft dysfunction and graft loss. Transplant 1999;67:918-922.

8. Egli A, Binggeli S, Bodaghi S, Dumoulin A, Funk GA, Khanna N, et al. Cytomegalovirus and polyomavirus BK posttransplant. Nephrol Dial Transplant 2007;22:72-82.

9. Hirsch HH, Knowles W, Dickenmann M, Passweg J, Klimkait T, Mihatsch MJ, et al. Prospective study of polyomavirus type BK replication and nephropathy in renal-transplant recipients. N Engl J Med 2002;347:488-496.

10. Nickeleit V, Singh HK, Mihatsch MJ. Polyomavirus nephropathy: morphology, pathophysiology, and clinical management. Curr Opin Nephrol Hypertens 2003;12:599605.

11. Mengel M, Marwedel M, Radermacher J, Eden G, Schwarz A, Haller $\mathrm{H}$, et al. Incidence of polyomavirus-nephropathy in renal allografts: influence of modern immunosuppressive drugs. Nephrol Dial Transplant 2003;18:1190-1196.

12. Dropulic LK, Jones RJ. Polyomavirus BK infection in blood and marrow transplant recipients. Bone Marrow Transplant 2008;41:11-18. 
13. Fogazzi GB, Cantu M, Saglimbeni L. 'Decoy cells' in the urine due to polyomavirus BK Infection: easily seen by phase-contrast microscopy. Nephrol Dial Transplant 2001;16:1496- 1498.

14. White MK, Khalili K. Pathogenesis of progressive multifocal leukoencephalopathy- revisited. J Infect Dis 2011;203:578-586.

15. Ferenczy MW, Marshall LJ, Nelson CD, Atwood WJ, Nath A, Khalili K, et al. Molecular biology, epidemiology, and pathogenesis of progressive multifocal leukoencephalopathy, the JC virus-induced demyelinating disease of the human brain.Clin Microbiol Rev 2012;25:471-506.

16. Berger JR. Progressive multifocal leukoencephalopathy in acquired immunodeficiency syndrome: Explaining the high incidence and disproportionate frequency of the illness relative to other immunosuppressive conditions. J NeuroVirol 2003;9:38-41.

17. Jiang $M$, Abend J, Johnson S, Imperiale MJ. The role of polyomaviruses in human disease. Virol 2009;384:266-273.

18. Matloubian M, Concepcion RJ, Ahmed R. CD4+ T cells are required to sustain $\mathrm{CD} 8+$ cytotoxic $\mathrm{T}$-cell responses during chronic viral infection. J Virol 1994;68:8056-8063.

19. Houff SA, Berger JR. The bone marrow, B cells, and JC virus. J Neurovirol 2008;14:341- 343.

20. Monaco MC, Atwood WJ, Gravell M, Tornatore CS, Major EO. JC virus infection of hematopoietic progenitor cells, primary B lymphocytes, and tonsillar stromal cells: implications for viral latency. J Virol 1996;70:7004-7012.

21. Chowdhury M, Kundu M, Khalili K. GA/GC-rich sequence confers Tat responsiveness to human neurotropic virus promoter, JCVL, in cells derived from central nervous system. Oncogene 1993;8:887-892.

22. Ensoli B, Barillari G, Salahuddin SZ, Gallo RC, Wong-Staal F. Tat protein of HIV-1 stimulates growth of cells derived from Kaposi's sarcoma lesions of AIDS patients. Nature 1990;345:84-86.

23. Jobes DV, Chima SC, Ryschkewitsch CF, Stoner GL. Phylogenetic analysis of 22 complete genomes of the human polyomavirus JC virus. J Gen Virol 1998;79:2491-2498.

24. Chen NN, Chang CF, Gallia GL, Kerr DA, Johnson EM, Krachmarov CP, et al. Cooperative action of cellular proteins YB-1 and Pur alpha with the tumor antigen of the human JC polyomavirus determines their interaction with the viral lytic control element. Proc Natl Acad Sci USA 1995;92:1087-1091.

25. De Gascun CF, Carr MJ. Human polyomavirus reactivation: Disease pathogenesis and treatment approahes. Clin Devel Immuno 2013;373579. doi: 10.1155/2013/373579

26. Gorrill T, Feliciano M, Mukerjee R, Sawaya BE, Khalili K, White MK. Activation of early gene transcription in polyomavirus BK by human immunodeficiency virus type 1 Tat. J Gen Virol 2006;87:1557-1566.

27. Hou J, Major EO. Progressive multifocal leukoencephalopathy:JC virus induced demyelination in the immune compromised host. J Neurovirol 2000;6:S98-S100.
28. Tan CS, Koralnik IJ. Progressive multifocal leukoencephalopathy and other disorders caused by JC virus: clinical features and pathogenesis. Lancet Neurol 2010;9: 425-437.

29. Berger JR, Houff S. Progressive multifocal leukoencephalopathy: lessons from AIDS and natalizumab. Neurol Res 2006;28:299-305.

30. Barouch DH, Faquin WC, Chen Y, Koralnik IJ, Robbins GK, Davis BT. BK virus- associated hemorrhagic cystitis in a Human Immunodeficiency Virus-infected patient. Clin Infect Dis 2002;35:326-329.

31. Cubukcu-Dimopulo O, Greco A, Kumar A, Karluk D, Mittal K, Jagirdar J. BK virus infection in AIDS. J Am J Surg Pathol 2000;24:145-149.

32. Shan KV, Ozer HL, Ghazey HN, Kelly TJ. Common structural antigen of papovaviruses of the simian virus 40-polyoma subgroup. J Virol 1977;21:179-186.

33. Neu U, Allen SA, Blaum BS, Liu Y, Frank M, Palma AS, et al. A structure-guided mutation in the major capsid protein retargets BK polyomavirus. PLoS Pathog 2013;9:e1003688.

34. Sala M, Vartanian JP, Kousignian P, Delfraissy JF, Taoufik Y, Wain-Hobson S, et al. Progressive multifocal leukoencephalopathy in human immunodeficiency virus type 1-infected patients: absence of correlation between JC virus neurovirulence and polymorphisms in the transcriptional control region and the major capsid protein loci. J Gen Virol 2001;82:899-907.

35. Sunyaev SR, Lugovskoy A, Simon K, Gorelik L. Adaptive mutations in the JC virus protein capsid are associated with progressive multifocal leukoencephalopathy (PML). PLoS Genet 2009;5:e1000368.

36. Stoner GL, Ryschkewitsch CF. Capsid protein VP1 deletions in JC virus from two AIDS patients with progressive multifocal leucoencephalopathy. J Neurovirol 1995;1:189194.

37. Tremolada S, Delbue S, Castagnoli L, Allegrini S, Miglio U, Boldorini R, et al. Mutations in the external loops of BK virus VP1 and urine viral load in renal transplant recipients. J Cell Physiol 2010;222:195-199.

38. Bauer PH, Bronson RT, Fung SC, Freund R, Stehle T, Harrison SC, et al. Genetic and structural analysis of a virulence determinant in polyomavirus VP1. J Virol 1995;69:7925-7931.

39. Darbinyan A, Siddiqui KM, Slonina D, Darbinian N, Amini S, White MK, et al. Role of JC virus agnoprotein in DNA repair. J Virol 2004;78:593-600.

40. Hirsch HH, Steiger J. Polyomavirus BK. Lancet Infect Dis 2003;3:611-623.

41. Pastrana DV, Brennan DC, Cuburu N, Storch GA, Viscidi RP, Randhawa PS, et al. Neutralization serotyping of BK polyomavirus infection in kidney transplant recipients. PloS Pathog 2012;8:e1002650.

42. Sharma PM, Gupta G, Vats A, Shapiro R, Randhawa PS. Polyomavirus BK non-coding control region rearrangements in health and disease. J Med Virol 2207;79:1199-120 